\title{
New Vision of Collaborative Networked Study: Fundamentals, Applications and Discipline Formation at CEFET/RJ
}

\author{
Antonio José Caulliraux Pithon \\ Federal Center of Technological Education CEFET/RJ, Avenida Maracanã, 229, \\ Bloco E, $5^{\circ}$ floor, Brazil \\ caulliraux@gmail.com
}

\begin{abstract}
Collaborative networks of organizations and/or can be nowadays found in large variety of forms, including virtual organizations, virtual enterprise, extended enterprise, dynamic supply chains, social network, etc. A large body of empiric knowledge related to collaborative networks is already available, but there is an urgent need to consolidated this knowledge and build the foundations for more sustainable development of this area. The establishment of a scientific discipline for collaborative networks is a strong instrument in achieving this purpose. In this context, the article presents the experience developed by Federal Center of Technological Education - CEFET/RJ Brazil that began, in the first semester of 2007, a pilot course on Collaborative Network for students in Master Program in Technology.
\end{abstract}

Keywords: Collaborative network, Social network, Virtual organization.

\section{Introduction}

The "term" network is nowadays a central issue in many fields like; social sciences, communications, physics, computer science, virtual organization, virtual enterprise, etc. Among the various types of network, of special relevance are collaborative networks. A collaborative network $(\mathrm{CN})$ is constituted by a variety of entities (e.g., organizations and people) that are largely autonomous in terms of their: operating environment, culture, social capital and goals. Nevertheless these entities collaborate to better achieve common of compatible goals, and whose interactions are supported by computer network (Camarinha-Matos, Afsarmanesh, 2005).

The implementation of collaborative process has accelerated in recent years as a consequence of both new challenges posed to companies and organizations by the fast changing socio-economic conditions and new developments in ICT sector.

In fact during the last three decades the information and communication technologies have been playing a growing role in organizations, namely as an instrument to support integration and flexibility. As a result of these developments, new scientific discipline emerged or where consolidated as in the case of collaborative Network (Camarinha-Matos et al., 2004). 
Nowadays, several courses in the specific area of Collaborative Network are already being taught or organized at different universities worldwide. For instance, the University of Lisbon (Portugal) offers a 1 semester course on Virtual enterprise to the $5^{\text {th }}$ year students of electrical and Computer engineering since 2002 (Garita, 2004).

Similarly, the Federal University of Santa Catarina (Brazil) offers course of Automation and Systems Engineering and the Costa Rica Institute of Technology [4] started offering Virtual Organization coursers to their students, as well as, on February 2007, Federal Center of Technological Education - CEFET/RJ in Brazil, stared a pilot course.

In the context, the objective of this paper is describe the experience with a pilot initiative of teaching a complete course on Collaborative Network (EDA 3022) at the Federal Center of Technological Education - CEFET/RJ in the Master Technological program in first trimester of 2007 academic year.

The proposal of this course is presented later on.

\section{Collaborative Network}

The word "net" is very old and it comes from the latin "retis", meaning interlacement of threads with regular openings that form a type of cloth. Starting from interlacement notion, mesh and reticular structures, the word net went winning new meanings along times, passing to be used in different situation.

Leaving of defined concept for (Cândido, et al, 2000.), "nets are organizational systems capable to gather individuals and institutions, of democratic form and share, around similar causes. Flexible structures and established horizon, the work dynamics in net suppose performances collaborative and sustained by the will and likeness of their members, being characterized as a significant organizational resource for the social structuring".

In agreement with, enterprise network are formed initially with objective of reducing uncertainties and risks, organizing economical activities starting from the coordination and cooperation among companies.

Most of the authors study the perspective of nets and her use, as a road to study the organizations, appears to the organizations as social nets and they should be analyzed as such. A social net has there to be with a group of people, organizations, etc., linked through a social relationships group of a specific type. In this perspective, the structure of any organization should be understood and analyzed in terms of multiple nets of internal and external relationships. In that sense, the organizations are nets and the organizational form depends on the characteristics, interests and needs participant companies.

The organizational nets can be considered a consequence of concepts and beginnings of social nets and they can be divided in intra and inter-organization.

We started to detail the several types of formations of nets below:

- Social Network: focus on relationship among social entities, is used widely in the social and behavioural sciences, as well as in economics, marketing, and industrial engineering;

- Virtual Organization: comprising a set of (legally) independent organizations that share resources and skills to achieve its mission/goal, but that is not limited to an 
alliance of for profit enterprises. A Virtual Enterprise is therefore, a particular case of Virtual Organization;

- Virtual Enterprise: a temporary alliance of enterprises that come together to share skills or core competencies and resources in order to better respond to business opportunities, and whose cooperation is supported by computer networks;

- Extended Enterprise: a concept typically applied to an organization in which a dominant enterprise "extended" its boundaries to all or some of its suppliers. An Extended Enterprise can be seen as a particular case of Virtual enterprise;

- Agile Enterprise: is the ability of an organization to adapt proficiently in continuously changing, unpredictable business environment;

- Joint Venture: is an entity formed between or more parties to undertake economic activity together. The parties agree to create a new entity by both contributing equity, and they share revenues, expenses, and control of the enterprise;

- Cluster: geographical concentrations of interlinked enterprises that act is a same section of specialized suppliers, providers services and associated institutions, tends in common, besides the location, the contribution for development products of region. They are orientated by beginnings as cooperation, complementarities, community's sense and competition.

In that sense, Collaborative Network course is being implanted, trying to give an approach of concepts mentioned above.

\section{Discipline Structure}

Collaborative network was included in 2007 as an optical discipline in Master Technological Program at CEFET/RJ and it is part of curricular structure and academic regime. These structure curricula are divided in a cast of obligatory and elective disciplines.

The distribution of those disciplines in curriculum of the course can be seen in Table 1.

The minimum duration for accomplishment of the course is 18 (eighteen) months and the maximum is 24 (twenty for) months. The course is divided in 3 (three) fundamentals steps, to know: obtaining the credits, development of research and defence of the dissertation.

During a period of 12 weeks, each week includes $4 \mathrm{~h}$ theory, these lectures comprised a presentation of the main concepts, state of the art and supporting technologies, and discussion of major trends and challenges. Although an optional discipline, this attracted 10 students in summer 2007, which is a significant number considering that was the first time that discipline was offered.

Offering this discipline, the Master's degree in Technology of CEFET/RJ answers directly to the student's longings, i.e., offers possibility the same ones know and learn on the emerging organizational concepts that will face in his professional life. The next sections describe in general terms the structure of Collaborative network discipline. 
Table 1. Distribution of discipline in Master's degree course

\begin{tabular}{|l|l|c|}
\hline \multicolumn{2}{|l|}{ Obligatory Disciplines } & Credit \\
\hline Code & Denomination & 3 \\
\hline MAD 3007 & Statistical Methods I & 3 \\
\hline EDA 3024 & Organization & 3 \\
\hline EDA 3025 & Technology & 0 \\
\hline EDA 3300 & Seminar for Master dissertation & 0 \\
\hline EDA 3301 & Research for Master dissertation & 3 \\
\hline Elective Disciplines & 0 \\
\hline EDA 3029 & Integrated Analysis of Life Cycle & 3 \\
\hline EDA 3302 & Study Activity Integrated & 3 \\
\hline EDA 3033 & Evaluation Projects & 3 \\
\hline EDA 3030 & Evaluation Technological Projects & 3 \\
\hline EDA 3012 & Systems Reliability & 3 \\
\hline EDA 3013 & Structural Reliability & 3 \\
\hline EDA 3014 & Human Reliability & 3 \\
\hline EDA 3022 & Corporate Finances & 3 \\
\hline EDA 3021 & Integration of Administration Systems & 3 \\
\hline EDA 3008 & Intelligence Computational & 3 \\
\hline EDA 3010 & Statistical Methods II & 3 \\
\hline EDA 3011 & Statistical Methods III & 3 \\
\hline EDA 3026 & Modelling of Phenomena & \\
\hline EDA 3022 & Collaborative Network & \\
\hline
\end{tabular}

\section{Structure of Collaborative Network Discipline}

Collaborative Network disciplines (EDA 3022) has as presupposition the fact that production of knowledge depends on the relationship among the subject (student) and the teacher. Thus, the discipline provided advanced education in the área of Collaborative Network, including Virtual Enterprises, Virtual Organization, Fractal Enterprise, Contracts in Virtual Organization, Social Network, etc.

The specific contents of the course are described bellow. For each subject the main bibliographic references that may be used.

\section{Network}

a) Introduction and concepts [27, 20, 18].

2. Network Models
a) Social network: definitions, application and examples [27, 2, 19];
b) Intra-organization Network: definition, application and examples [12];
c) Inter-organization Network: definition, application and examples [12];
d) Interpersonal Network: definition, application and examples [12].

3. Virtual Organization $[14,6]$
a) Agile Enterprise [15, 23];
b) Virtual Enterprise [6, 21, 23];
c) Extended Enterprise [3];
d) Fractal Enterprise [25];
e) Life cycle [10, 28]; 
f) Contracts in Virtual Organization (legal form) [26];

g) Broker in Virtual Enterprise Formation: [23, 1];

h) Teams in Virtual Enterprise: [23].

4. Cooperative Network

a) Joint Ventures [22];

b) Cluster [24];

c) Scientific Collaborative Network [9].

5) Awareness in Network

a) Introduction e definitions [13].

\section{Objectives of the Course}

Collaborative network discipline has how main objectives to do the students are capable of:

- In-depth study of $\mathrm{CN}$ paradigm focusing on related information technologies and concrete applications;

- Identify and develop possible subjects for pos-graduation theses/projects;

- Explore the application of CN concepts within a national context;

- Develop in the students basic skills to carry out applied research and publish the corresponding scientific results;

- Aim at the establishment of a research group on $\mathrm{CN}$ at the Collaborative Work Nucleus.

\section{Discipline Practical Activities}

The activity developed at classroom is based in the games as tool that makes possible business existence simulation in their several activities, including from the planning to execution. This technique is very used, mainly in the administration courses, masters degree and MBA's and it portrays, in an informal way and to entertaining, strategies to be adopted by managers in the execution of the tasks, mainly in those that it involves work team, focus of our experiment.

The accomplished experience tried to show the importance of concepts learned at classroom, concerning the structure of a collaborative Network and all their interfaces concerning obtaining of their results. It fits to detach that the exercise happened in real time and attendance, because, it is not very common once the nets operate in virtual way.

The team, composed for team students, a consultant (invited teacher) and the director of enterprise (teacher of the discipline), it was under the consultant's orientation, positioned with the hands given in circle form, halfway some of other ones, in the classroom.

The disposition in circle is due to fact the communication if to give in a lot of directions and his flow is not controlled, just administered, that is, doesn't possess a hierarchy. The consultant distributed numbers written in a piece of paper (from 1 to 10), so that it was put in the ground ahead of the feet of each team member, passing to be this identification numbering of each one. To proceed, the consultant distributed 
string pieces with approximately 2,5 meters in length, that crossing in diagonal, it tied for the tips each member the other, tends these to tie one of the tips of string in right pulse (Figure 1). In this dispositions and already connected, the consultant explained the game rule that consisted beforehand, in the choice manager on the part of team. Tends the manager been chosen, the consultant request to the same as does the annotations related with what will happen.

At this time, he consultant begins the change of positions of each one in the circle, and in the end of those changes, he grew up a true knot in the string, as seen in the Figure 1. That knots the events that happen the any net type acts, since for beginning, the social nets are not static. The manager's paper was driving the actions that they would be developed by group, in the sense of untying the knot. It was not allowed that in any hypothesis, the string that tied each member of the group was cut and the knot that tied him to the undone pulse. The established time so that the manager drove his task was 5 minutes.

Therefore in beginning, it was noticed that manager didn't stop the control task and nor command of the team, letting his insecurity to appear for the group. With the control loss on the part of manager, the group began showing in a disordered way, random and empiric with objective of undoing knot. Visibly amazed, the team unchained a series of disconnected manifestations that disrupt the search of solution for the problem. The time of five minutes became exhausted and the result was not reached.

Before this problem, the consultant undid the net and it substituted the manager for other member of the group. Starting from this substitution, the group through a disassemble process, got to complete the exercise in the stipulated period of five minutes.

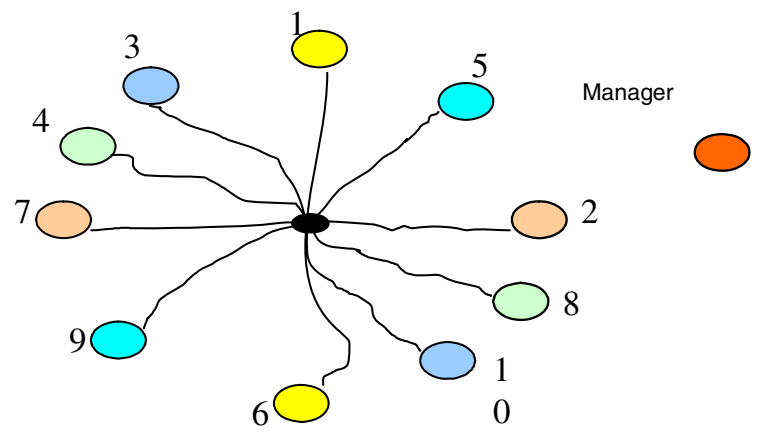

Fig. 1. Teams formation

At the end of the experiment, the teacher of discipline made an analogy with the net concepts, where the collaboration and the trust are fundamental for the development of net.

\section{Conclusion}

Introduction of Collaborative network discipline in master technological Program at CEFET/RJ, although an optional discipline, is being successful and contributing to 
preparation of a new generation of engineers and research able to play a major role in the deployment of Collaborative network concept in Brazilian university.

The assertiveness of result this experience is in the number of students that intend to include concepts of collaborative network as theoretical establish (or regarding analysis) in their theme of dissertation research.

As a result, the course is planned to be given again in coming semesters in this program.

Regarding future horizon, the possibility of offering a Virtual Course on Collaborative Network in Spanish (using e-learning techniques) aiming at integration Universities and Institutes of Technology of Latin America and Caribbean countries, can be evaluated.

Finally, it is clear more textbooks in this area are necessary in order to facilitate education tasks.

\section{References}

1. Ávila, P., Putnik, G., et al.: Brokerage function in Agile Virtual Enterprise Integration - A Literature Review. In: Camarinha-Matos, L.M. (ed.) Collaborative Business Ecosystems and Virtual Enterprise. Kluwer Academic Publisher, Dordrecht (2002)

2. Burt, R.S., Minor, M.J.: Applied Networks Analysis. Sage, Berverly Hills (1983)

3. Browne, J.: The Extended Enterprise - Manufacturing and the Value chain. In: Afsarmanesh, H. (ed.) Balanced Automation Systems - Architectures and design Methodologies (1995)

4. Camarinha-Matos, L.M., Afsarmanesh, H.: Journal of Intelligent Manufacturing 1(16), 439-452 (2005)

5. Camarinha-Matos, L.M., Cardoso, T.: Education on Virtual Organizations: Na experience at UNL. In: Virtual Enterprise and Collaborative Networks. Kluwer Academic Publisher, Boston (2004)

6. Camarinha-Matos, L.M., Afsarmanesh, H.: The Virtual Enterprise concept. In: CamarinaMatos, L.M., Afsarmanesh, H. (eds.) Infrastructure for Virtual enterprise - Networking Industrial Enterprise, pp. 3-14. Kluwer Academic, Dordrecht (1999)

7. Cândido, G.A., Abreu, A.F.: Os conceitos de redes e as relações inter-organizacionais: um estudo exploratório. In: ENANPAD, Florianópolis, Brasil (2000)

8. Cheng, K.: E-Manufacturing: Fundamentals and Applications (Ed.). WIT Press, London (2005)

9. Dias dos Santos, P.: Redes de Colaboração Científica Interdisciplinares: estudo de caso na Rede Brasileira de Universidades Federais. XXXI Congresso Brasileiro de Ciências da Comunicação - Natal (2008)

10. Fuchs, M.: Design and Implementation of value Systems: The Lifecycle Perspective. Institute for Technology Mabagement, Universty of St. Gallen, Switerland (1999)

11. Garita, C.: A case study of VO education in Costa Rica. In: Virtual enterprise and Collaborative Network. Kluwer Academic Publisher, Boston (2004)

12. Grandori, A., Soda, G.: Inter Firm Networks: Antecedentes, Mechanism and Forms (1995)

13. Gutwin, C., Greenberg, S.: The Importance of Awareness for team Cognition in Distributed Collaboration. In: Salas, E., Fiore, S.M. (eds.) Team Cognition: Understanding the factors that drive Process and Performance, pp. 177-201 (2004)

14. Jägers, H., Jansen, W.: Characteristics of Virtual organization. In: Sieber, P., Griese, J. (eds.) Organization Virtualness, pp. 65-76. Simowa Verlag Bern (1998) 
15. Lee, G.H.: Designs of Components and manufacturing Systems for Agile Manufacturing. International Journal of Production Research, 1023-1044 (1998)

16. Leon, M.E.: Uma Análise de Redes de Cooperação das Pequenas e Médias Empresas do Setor de Telecomunicações. Dissertação de Mestrado, Engenharia de Produção da Escola Politécnica da Universidade de São Paulo (1998)

17. Lipnak, J., Stamps, J.: Virtual Teams: People Working Across Boundaries with Technology. John Wiley \& Sons, Inc., Chichester (2000)

18. Loiola, E., Moura, S.: Análise de Redes: Uma contribuição aos Estudos Organizacionais. In: Fischer, T. (Org). Gestão Contemporânea: cidades estratégicas e organizações locais, Rio de Janeiro, pp. 53-68 (2007)

19. Martelo, R.M.: Análise das Redes Sociais - aplicação nos estudos de transferência da informação. Revista Ciência e Informação 30(1), 71-81 (2001)

20. Noria, N.: Is a network perspective a useful way of studying organizations? In: Nohria, N., Eccles, R.G. (eds.) Network and Organizations: structure, form and action, pp. 1-22. Harvard Business School Press, Boston (1992)

21. Osório, L., Barata, M., Gibon, P.: Communication Infrastructures Requirements in a Virtual Enterprise. In: Camarinha-Matos, L.M., Afsarmanesh, H. (eds.) Infrastructure for Virtual Enterprises - Networking Industrial Enterprises, pp. 65-76. Kluwer Academic, Dordrecht (1999)

22. Pimenta, E.G.: Joint Ventures - Contratos de Parceria Empresarial no Direito Brasileiro, Juarez de Oliveira Editora (2005)

23. Pithon, A.J.C.: Projeto Organizacional para a Engenharia Concorrente no Âmbito das Empresas Virtuais. Ph.D. Thesis, University of Minho, Guimarães, Portugal (2004)

24. Porter, M.: Clusters and the new economics of competition. Harvard Business Review (1998)

25. Rajan, V.N.: An Agent-Based Fractal model of Agile manufacturing Enterprises: Modeling and Decision-Making Issues. In: Proceedings of the Al and Manufacturing Research Planning Workshop (1996)

26. Teixeira, B.M.: Proposta de um Modelo Contratual para as Empresas Virtuais no Âmbito da Legislação Brasileira. M.Sc Thesis, CEFET/RJ, Rio de Janeiro (2007)

27. Yoguel, G., Kantis, H.: Reestructuración Industrial y Eslabonamientos Productivos: El rol de las pequeñas y Medianas Firmas Subcontratistas. Buenos Aires, CEPAL (1990)

28. Zimmermman, F.: Structural and Managerial Aspects of Virtual Enterprise. University of Bamberg, Business Information Systems (1996) 